\title{
HEXAVALENT CHROMIUM ADSORPTION REMOVAL FROM AQUEOUS SOLUTION BY FE-MODIFIED BIOCHAR DERIVED FROM RICE STRAW
}

\author{
FAN, L. Q. $.^{1,2^{*}}-$ LIU, Q. ${ }^{1,2}-$ WAN, Y. ${ }^{1,2}-$ WANG, X. D. ${ }^{1,2}-$ MIAO, J. X. ${ }^{1,2}-$ CAI, J. ${ }^{3}-$ CHEN, W..$^{1,2}$ \\ - CHEN, F. H. ${ }^{1,2}-$ CHENG, L. ${ }^{1,2}-$ JI, L. ${ }^{1,2}-$ LUO, H. B. ${ }^{1,2}$ \\ ${ }^{1}$ College of Civil Engineering, Sichuan Agricultural University, Dujiangyan 611830, China \\ ${ }^{2}$ Sichuan Higher Education Engineering Research Center for Disaster Prevention and \\ Mitigation of Village Construction, Sichuan Agricultural University, Dujiangyan 611830, China
}

${ }^{3}$ Department of Physical and Chemical Analysis, Dujiangyan Center for Disease Control and Prevention, Dujiangyan 611830, China

*Corresponding author

e-mail:flqjacky@163.com

(Received $8^{\text {th }}$ Jul 2019; accepted $15^{\text {th }}$ Nov 2019)

\begin{abstract}
In this study, Fe-modified biochar (Fe-R-BC) was made from rice straw by modified with $\mathrm{FeCl}_{3}$ through pyrolysis, and used to adsorb $\mathrm{Cr}(\mathrm{VI})$ from aqueous solution. The properties of Fe-R-BC and rice straw biochar (R-BC) were characterized by Fe content, Brunauer-Emmett-Teller (BET) analysis, Boehm titration, and Fourier-transform infrared (FT-IR) spectroscopy. The Cr(VI) adsorption removal mechanism and regenerative property of Fe-R-BC were explored with batch adsorption experiment. Compared to those of R-BC, the Fe content, specific surface area (BET), total pore volume, and amount of hydroxyl group of Fe-R-BC increased, while the average pore size and amount of methenyl group decreased. For Fe-R-BC, the maximum $\mathrm{Cr}(\mathrm{VI})$ adsorption removal capacity was $94.95 \mathrm{mg} \cdot \mathrm{g}^{-1}$ at $313 \mathrm{~K}$. The $\mathrm{Cr}(\mathrm{VI})$ adsorption kinetics and isotherms can be well described by the pseudo second order model and the LangmuirFreundlich model, respectively. The Cr(VI) adsorption removal was spontaneous and endothermic. Low $\mathrm{pH}$ was beneficial for the $\mathrm{Cr}(\mathrm{VI})$ adsorption removal. $\mathrm{SO}_{4}{ }^{2-}$ showed the largest influence on the $\mathrm{Cr}(\mathrm{VI})$ adsorption removal, followed by $\mathrm{NO}_{3}{ }^{-}$and $\mathrm{Cl}^{-}$. After 4 sorption-desorption cycles, the regenerated $\mathrm{Fe}-\mathrm{R}-\mathrm{BC}$ still maintained $76.27 \%$ of adsorption removal ability compared to that of Fe-R-BC in the initial use. Overall, Fe-R-BC can be applied to treat wastewater containing $\mathrm{Cr}(\mathrm{VI})$.
\end{abstract}

Keywords: rice straw biochar, modification, property, hexavalent chromium, adsorption removal mechanism

\section{Introduction}

Chromium and its alloys are widely used in daily life and industrial production. With the development of economy, the demanded quantity of chromium and its alloys grows with each passing day. As a result, a large amount of wastewater containing chromium (Cr) was produced in recent decades. Two valence states, i.e., $\mathrm{Cr}$ (III) (trivalent chromium) and $\mathrm{Cr}(\mathrm{VI})$ (hexavalent chromium), were the main occurrence forms of $\mathrm{Cr}$ in these wastewaters. Compared with $\mathrm{Cr}(\mathrm{III}), \mathrm{Cr}(\mathrm{VI})$ has higher carcinogenicity and mutagenicity (Liu et al., 2010). In view of this, many countries and organizations listed $\mathrm{Cr}(\mathrm{VI})$ as one of the strictly controlled heavy metals in industrial wastewater (Ma et al., 2014). That is to say, before discharging the industrial wastewater containing $\mathrm{Cr}(\mathrm{VI})$, its concentration should be strictly controlled.

There are various methods to remove heavy metals from wastewater such as electrochemical treatment (Golder et al., 2011; Mella et al., 2015), ionic exchange (Rafati et al., 2010), membrane filtration (Soylak et al., 2007), adsorption (Liu et al., 
2010). Among these methods, adsorption was regarded as a valid and dependable method to remove heavy metals, which could avoid some disadvantages of other methods, such as the high cost of equipment, production of toxic sludge and other wastes (Baran et al., 2007; Liu et al., 2010). For adsorption method, the treatment effectiveness depends primarily on the adsorbent used (Gu et al., 2005). At present, activated carbon (Kaveeshwar et al., 2018), bioadsorbents (Gupta et al., 2015), zeolite (Wang and Peng, 2010), clay minerals (Uddin, 2017), biochar (Dong et al., 2011; Xu et al., 2013; Inyang et al., 2016), etc. are commonly used as adsorbents. Among these adsorbents, biochar was considered as an emerging and promising adsorbent in view of its low cost and sustainability (Chun et al., 2004; Ahmad et al., 2014; Park et al., 2016a). However, the original biochar has a low adsorption capacity for heavy metals (Zhou et al., 2013; Ma et al., 2014). In recent years, many physical and chemical modification methods have been used to improve the adsorption capacity of biochar (Rajapaksha et al., 2016). For example, Park et al. (2016b) reported that steam activation significantly enhanced the adsorption capacity of red macroalga Porphyra tenera biochar for $\mathrm{Cu}$. Ding et al. (2016) found alkali modification promoted the adsorption capacity of hickory wood biochar for $\mathrm{Pb}, \mathrm{Cu}, \mathrm{Cd}, \mathrm{Zn}$, and $\mathrm{Ni}$. Zhou et al. (2017) indicated that introduction of nano- $\mathrm{MnO}_{2}$ on corn stalk biochar improved its adsorption capacity for $\mathrm{Cu}$.

Rice straw is a kind of common agricultural waste. In China, about 201.0-301.5 million tons of rice straw was generated per year (Jiang et al., 2015). To realize the sustainable development of agriculture, the Chinese government has been sparing no effort to encourage and promote resource utilization technology of rice straw in recent years. Converting rice straw to biochar not only can achieve reutilization of rice straw, but also can benefit carbon-emission reduction. Thus, biochar technology was considered as an effective resource technology for rice straw. At present, rice straw biochar (R-BC) was successfully applied to remove different heavy metals from wastewater (Han et al., 2013; Pan et al., 2013; Xu et al., 2014; Park et al., 2017; Dong et al., 2018). Nevertheless, modification of R-BC could further enhance its utilization efficiency considering the advantage of modification technology for heavy metal adsorption. In the previous studies, Fe oxides were found to have the good selectivity and affinity to $\mathrm{Cr}$ (VI) (Tzou et al., 2003). In recent years, Agrafioti et al. (2014) also found that the sewage sludge biochar with high Fe content had higher adsorption rate of $\mathrm{Cr}(\mathrm{VI})$ compared with the other two biomass-based biochars. Thus, the $\mathrm{Cr}(\mathrm{VI})$ adsorption capacity of $\mathrm{R}-\mathrm{BC}$ is expected to be promoted by introducing $\mathrm{Fe} / \mathrm{Fe}$ oxides onto it.

In this study, R-BC and Fe-modified R-BC (Fe-R-BC) were prepared firstly. Then, the properties of R-BC and Fe-R-BC (i.e., the yield, Fe content, specific surface area (BET), total pore volume, average pore size, number of acidic and basic surface functional groups, and category of surface functional group) were compared. After that, a series of batch experiments including adsorption kinetic, adsorption isotherms, initial solution $\mathrm{pH}$, and coexisting ions influence were performed. Moreover, the regenerative property of Fe-R-BC was evaluated by several cycles of adsorption-desorption experiment. The purposes of this study are to (1) characterize the properties of Fe-R$\mathrm{BC},(2)$ explore the $\mathrm{Cr}(\mathrm{VI})$ adsorption removal mechanism of Fe-R-BC, and (3) evaluate the regenerative performance of Fe-R-BC. 


\section{Materials and methods}

\section{Preparation of $R-B C$ and Fe-R-BC}

Rice straw was gathered from Shuangliu County, Sichuan province, China. The gathered rice straw was washed several times with tap water and dried in the air. Then the rice straw was smashed and sieved through a screen (10-mesh). The sieved rice straw was divided into two parts. One part was soaked in the $\mathrm{FeCl}_{3}$ solution $(1 \mathrm{M}, \mathrm{m} / \mathrm{v}$ $(\mathrm{g} / \mathrm{mL})=1 / 10)$ for $48 \mathrm{~h}$ at room temperature. After that, the Fe-soaked rice straw was separated by filtration and dried at $333 \mathrm{~K}$ to constant weight. The Fe-soaked rice straw and the other part of pristine rice straw were respectively putted into the different crucibles with covers and pyrolyzed for $2 \mathrm{~h}$ in a muffle furnace (SX2-4-10, Shenyang Energy Saving Electric Furnace Factory, Shenyang, China) at 673 K. After pyrolyzed, the carbonized pristine rice straw was smashed again and sieved through a screen (60mesh). The sieved carbon material was R-BC. For the carbonized Fe-soaked rice straw, it was rinsed several times with $3 \mathrm{M} \mathrm{HCl}$ to remove excessive iron. And then, the carbonized Fe-soaked rice straw was washed several times with deionized water (18.25 $\mathrm{M} \Omega$ ). After that, the carbonized Fe-soaked rice straw was dried at $333 \mathrm{~K}$ to constant weight. At last, the carbonized Fe-soaked rice straw was ground and sieved through a screen (60-mesh). The sieved powder was Fe-R-BC.

\section{Property detection}

The yield was determined by the following Equation 1:

$$
\text { Yield }(\%)=\left(\frac{m_{a}}{m_{b}}\right) \times 100 \%
$$

where $\mathrm{m}_{\mathrm{a}}$ refers to the acquired $\mathrm{R}-\mathrm{BC}$ or Fe-R-BC mass $(\mathrm{g}), \mathrm{m}_{\mathrm{b}}$ denotes the rice straw mass $(\mathrm{g})$.

The specific surface area (BET), total pore volume, and average pore size were measured using a specific surface area analyzer (NOVA-1200, Quantachrome Corp., Boynton Beach, Florida, USA) with $\mathrm{N}_{2}$ adsorption method (Dong et al., 2011). The quantities of acidic and basic surface functional groups were quantified using Boehm titration (Giannakoudakis et al., 2016). The category of surface functional group was determined by FT-IR spectrometer (Spectrum II, Perkin-Elmer Crop., Norwalk, OH, USA). For the Fe content in R-BC or Fe-R-BC, $0.10 \mathrm{~g}$ R-BC or Fe-R-BC was digested with $\mathrm{HNO}_{3}$ using microwave digestion method, and the Fe concentration in the digestion solutions was detected using a flame atomic absorption spectrometer (PinAAcle 900T, PerkinElmer Management (Shanghai) Co., Ltd., Shanghai, China) to calculate its content. Furthermore, the zeta potential of Fe-R-BC was determined using a zeta potentiometer (JS94H2M, Shanghai Zhongcheng Digital Technology Equipment Co., Ltd., Shanghai, China) to explain the influence of initial solution $\mathrm{pH}$ on $\mathrm{Cr}(\mathrm{VI})$ adsorption removal.

\section{Batch adsorption experiments}

Adsorption kinetics: $0.10 \mathrm{~g}$ R-BC or Fe-R-BC was added into $50 \mathrm{~mL} \mathrm{Cr}(\mathrm{VI})$ solution (100 mg $\cdot \mathrm{L}^{-1}$, prepared with $\mathrm{K}_{2} \mathrm{Cr}_{2} \mathrm{O}_{7}$ ). Then, the initial $\mathrm{pH}$ value of the mixed solution was adjusted to 2.0. After that, the mixed solution was placed in a constant temperature oscillation box (TS-2012C, Shanghai Xiren Scientific Instruments Co., Ltd., Shanghai, 
China) to experience a predefined time period $(0.5,1,2,4,6,8,10,12,16,20$, and $24 \mathrm{~h}$, respectively) at $120 \mathrm{rpm}$ and $298 \mathrm{~K}$.

Adsorption isotherms: $0.10 \mathrm{~g} \mathrm{Fe}-\mathrm{R}-\mathrm{BC}$ was added into $50 \mathrm{~mL} \mathrm{Cr}(\mathrm{VI})$ solution with a certain concentration $\left(75,100,200,300,400,500,600\right.$, and $800 \mathrm{mg} \cdot \mathrm{L}^{-1}$, respectively). Then, the initial $\mathrm{pH}$ value of the mixed solution was adjusted to 2.0. After that, the mixed solution was placed in the constant temperature oscillation box for $24 \mathrm{~h}$ at $120 \mathrm{rpm}$ and a fixed temperature $(283 \mathrm{~K}, 298 \mathrm{~K}$, and $313 \mathrm{~K}$, respectively).

Initial solution $\mathrm{pH}$ : $0.10 \mathrm{~g}$ Fe-R-BC was added into $50 \mathrm{~mL} \mathrm{Cr}(\mathrm{VI})$ solution $\left(100 \mathrm{mg} \cdot \mathrm{L}^{-1}\right)$. Then, the initial $\mathrm{pH}$ value of the mixture solution was adjusted to a predesigned value $(2.0,3.0,4.0,5.0,6.0,7.0$, and 8.0, respectively). After that, the mixed solution was placed in the constant temperature oscillation box for $24 \mathrm{~h}$ at $120 \mathrm{rpm}$ and $298 \mathrm{~K}$.

Coexisting ions influence: $0.10 \mathrm{~g}$ Fe-R-BC was added into $50 \mathrm{~mL} \mathrm{Cr}(\mathrm{VI})$ solution $\left(100 \mathrm{mg} \cdot \mathrm{L}^{-1}\right)$. Then, the coexisting ion concentration $\left(\mathrm{Cl}^{-}\right.$or $\mathrm{NO}_{3}{ }^{-}$or $\left.\mathrm{SO}_{4}{ }^{2-}\right)$ in the mixture was adjusted to a predetermined value $(0.005,0.01,0.02,0.05,0.10,0.20,0.50,1.0$, and $2.0 \mathrm{M}$, respectively). After that, the initial $\mathrm{pH}$ value of the mixed solution was adjusted to 2.0. At last, the mixed solution was placed in the constant temperature oscillation box for $24 \mathrm{~h}$ at $120 \mathrm{rpm}$ and $298 \mathrm{~K}$.

Adsorption-desorption experiment: Four cycles of adsorption-desorption were conducted in this experiment to evaluate the regenerative property of Fe-R-BC. A cycle of adsorption-desorption was described as follows: $0.10 \mathrm{~g}$ Fe-R-BC was added into 50 $\mathrm{mL} \mathrm{Cr}(\mathrm{VI})$ solution $\left(100 \mathrm{mg} \cdot \mathrm{L}^{-1}\right)$. Then, the initial $\mathrm{pH}$ value of the mixed solution was adjusted to 2.0. After that, the mixed solution was placed in the constant temperature oscillation box for $24 \mathrm{~h}$ at $120 \mathrm{rpm}$ and $298 \mathrm{~K}$. Afterwards the mixture was separated by filtering. The separated adsorbent was added into $50 \mathrm{~mL} \mathrm{NaOH}$ solution $(0.1 \mathrm{M})$, and shaken at $298 \mathrm{~K}$ for $24 \mathrm{~h}$. After that was done, the adsorbent was separated and washed several times with deionized water. The washed adsorbent was used to the next cycle of adsorption-desorption.

After each treatment was completed, the residual $\mathrm{Cr}(\mathrm{VI})$ concentration in the solution was analyzed using a UV-vis spectrophotometer (UV-1800, Shanghai Mapada Instruments Co., Ltd., Shanghai, China) with 1,5-diphenylcarbohydrazide spectrophotometric method. The $\mathrm{Cr}(\mathrm{VI})$ adsorption removal rate (AR, \%) and the $\mathrm{Cr}(\mathrm{VI})$ adsorption removal amount at equilibrium $\left(\mathrm{q}_{\mathrm{e}}, \mathrm{mg} \cdot \mathrm{g}^{-1}\right)$ were calculated by the following Equations 2-3, respectively.

$$
\begin{gathered}
\mathrm{AR}=\left(\frac{\mathrm{C}_{0}-\mathrm{C}_{\mathrm{i}}}{\mathrm{C}_{0}}\right) \times 100 \% \\
\mathrm{q}_{\mathrm{e}}=\frac{\left(\mathrm{C}_{0}-\mathrm{C}_{\mathrm{i}}\right) \times 0.05}{0.10}
\end{gathered}
$$

where $\mathrm{C}_{0}$ and $\mathrm{C}_{\mathrm{i}}$ denotes the initial and residual $\mathrm{Cr}(\mathrm{VI})$ concentration in each treatment, respectively.

\section{Modeling}

In this study, the pseudo first order model, the pseudo second order model, and the intraparticle diffusion model were used to fit the adsorption kinetics data. The following 
Equations 4-6 gives the function expression of the above three models, respectively (Wu et al., 2017).

The pseudo first order model:

$$
\mathrm{q}_{\mathrm{t}}=\mathrm{q}_{\mathrm{e}}\left(1-\exp ^{-\mathrm{k}_{1}, \mathrm{t}}\right)
$$

The pseudo second order model:

$$
\mathrm{q}_{\mathrm{t}}=\frac{\mathrm{tq}_{\mathrm{e}}{ }^{2} \mathrm{k}_{2}}{1+\mathrm{tq}_{\mathrm{e}} \mathrm{k}_{2}}
$$

The intraparticle diffusion model:

$$
\mathrm{q}_{\mathrm{t}}=\mathrm{k}_{3} \mathrm{t}^{0.5}+\mathrm{C}
$$

where $\mathrm{q}_{\mathrm{t}}$ represents the $\mathrm{Cr}(\mathrm{VI})$ adsorption removal amount at time $\mathrm{t}\left(\mathrm{mg} \cdot \mathrm{g}^{-1}\right) \cdot \mathrm{k}_{1}\left(\mathrm{~h}^{-1}\right), \mathrm{k}_{2}$ $\left(\mathrm{g} \cdot \mathrm{mg}^{-1} \cdot \mathrm{h}^{-1}\right)$, and $\mathrm{k}_{3}\left(\mathrm{mg} \cdot \mathrm{g}^{-1} \cdot \mathrm{h}^{-1 / 2}\right)$ are the reaction rate constants. $\mathrm{C}$ is a constant $\left(\mathrm{mg} \cdot \mathrm{g}^{-1}\right)$.

The Freundlich isotherm model, the Langmuir isotherm model, and the LangmuirFreundlich isotherm model were used to simulate adsorption isotherms. The following Equations 7-9 gives the function expression of the above three models, respectively (Jung et al., 2015).

The Freundlich isotherm model:

$$
\mathrm{q}_{\mathrm{e}}=\mathrm{K}_{\mathrm{F}} \times \mathrm{C}_{\mathrm{e}}^{1 / \mathrm{n}}
$$

The Langmuir isotherm model:

$$
\mathrm{q}_{\mathrm{e}}=\frac{\mathrm{q}_{\mathrm{m}} \mathrm{K}_{\mathrm{L}} \mathrm{C}_{\mathrm{e}}}{1+\mathrm{K}_{\mathrm{L}} \mathrm{C}_{\mathrm{e}}}
$$

The Langmuir-Freundlich isotherm model:

$$
\mathrm{q}_{\mathrm{e}}=\frac{\mathrm{q}_{\mathrm{m}} \mathrm{KC}_{\mathrm{e}}{ }^{1 / n}}{1+\mathrm{KC}_{\mathrm{e}}{ }^{1 / \mathrm{n}}}
$$

where $\mathrm{q}_{\mathrm{m}}$ represents the $\mathrm{Cr}(\mathrm{VI})$ maximum adsorption removal capacity $\left(\mathrm{mg} \cdot \mathrm{g}^{-1}\right), \mathrm{C}_{\mathrm{e}}$ is the equilibrium concentration $\left(\mathrm{mg} \cdot \mathrm{L}^{-1}\right), \mathrm{K}_{\mathrm{F}}\left(\left(\mathrm{mg} \cdot \mathrm{g}^{-1}\right) \cdot\left(\mathrm{L} \mathrm{mg}^{-1}\right)^{1 / \mathrm{n}}\right), \mathrm{K}_{\mathrm{L}}\left(\mathrm{L} \cdot \mathrm{mg}^{-1}\right)$ and $\mathrm{K}\left(\mathrm{L} \cdot \mathrm{mg}^{-1}\right)$ are the constants, and $1 / \mathrm{n}$ is the heterogeneity factor.

The thermodynamics of the adsorption processes were estimated by three important thermodynamic parameters (i.e., $\Delta \mathrm{G}^{0}$ (Gibbs free energy, $\mathrm{kJ} \cdot \mathrm{mol}^{-1}$ ), $\Delta \mathrm{H}^{0}$ (enthalpy, $\mathrm{kJ} \cdot \mathrm{mol}^{-1}$ ), and $\Delta \mathrm{S}^{0}$ (entropy, $\left.\mathrm{kJ} \cdot \mathrm{mol}^{-1} \cdot \mathrm{K}^{-1}\right)$ ). And they were calculated based on the results of adsorption isotherms by using the following Equations 10,11.

$$
\ln \mathrm{K}_{\mathrm{c}}=-\frac{\Delta \mathrm{H}^{0}}{\mathrm{RT}}+\frac{\Delta \mathrm{S}^{0}}{\mathrm{R}}
$$




$$
\Delta \mathrm{G}^{0}=-\mathrm{RT} \ln \mathrm{K}_{\mathrm{c}}
$$

where $\mathrm{K}_{\mathrm{c}}$ denotes the adsorption equilibrium constant $\left(\mathrm{L} \cdot \mathrm{g}^{-1}\right)$, which can be acquired by plotting $\ln \left(\mathrm{q}_{\mathrm{e}} / \mathrm{C}_{\mathrm{e}}\right)$ vs. $\mathrm{C}_{\mathrm{e}}$ (Gan et al., 2015). $\mathrm{T}$ is the absolute temperature (K). $\mathrm{R}$ represents the universal gas constant.

\section{Data processing}

All treatments were conducted in triplicate, and the average value of three replicates was taken as the experimental result. Excel 2007 and Origin 2018 were used for data management, processing, and drawing. Moreover, one-way ANOVA analysis was used to analyze the significant differences of the experimental data with IBM SPSS Statistics 22.

\section{Results and discussion}

\section{Properties of $R-B C$ and $F e-R-B C$}

Table 1 shows the yield, Fe content, specific surface area (BET), total pore volume, average pore size, and numbers of acidic and basic surface functional groups of R-BC and Fe-R-BC. The yield of R-BC and Fe-R-BC was $40.30 \%$ and $36.20 \%$, respectively $(\mathrm{p}<0.05)$. As a result of modification with $\mathrm{FeCl}_{3}, \mathrm{Fe}-\mathrm{R}-\mathrm{BC}$ had a higher $\mathrm{Fe}$ content than $\mathrm{R}-\mathrm{BC}(\mathrm{p}<0.05)$. Compared to those of R-BC, the specific surface area (BET) and total pore volume of Fe-R-BC increased by $24.16 \mathrm{~m}^{2} \cdot \mathrm{g}^{-1}$ and $0.91 \mathrm{~cm}^{3} \cdot \mathrm{g}^{-1}$, respectively, while the average pore size decreased by $2.63 \mathrm{~nm}$. The number of basic groups of $\mathrm{Fe}-\mathrm{R}-\mathrm{BC}$ was $0.23 \mathrm{mmol} \cdot \mathrm{g}^{-1}$, which significantly lower than that of R-BC $\left(0.62 \mathrm{mmol} \cdot \mathrm{g}^{-1}\right)(\mathrm{p}<0.05)$. On the contrary, the number of acid groups of Fe-R-BC $\left(0.56 \mathrm{mmol} \cdot \mathrm{g}^{-1}\right)$ increased compared to that of $\mathrm{R}-\mathrm{BC}\left(0.53 \mathrm{mmol} \cdot \mathrm{g}^{-1}\right)(\mathrm{p}<0.05)$.

Table 1. Yield, Fe content, specific surface area (BET), total pore volume, average pore size, and numbers of acidic and basic surface functional groups of $R-B C$ and $F e-R-B C$

\begin{tabular}{c|c|c|c|c|c|c|c}
\hline Designation & Yield (\%) & Fe $\left(\mathbf{m g} \cdot \mathbf{g}^{-1}\right)$ & $\begin{array}{c}\text { SSA } \\
\left(\mathbf{m}^{\mathbf{2}} \cdot \mathbf{g}^{-1}\right)\end{array}$ & $\begin{array}{c}\text { TPV } \\
\left(\mathbf{c m}^{\mathbf{3}} \cdot \mathbf{g}^{-1}\right)\end{array}$ & APS (nm) & $\begin{array}{c}\text { BG } \\
\left(\mathbf{m m o l} \cdot \mathbf{g}^{-1}\right)\end{array}$ & $\begin{array}{c}\text { AG } \\
\left(\mathbf{m m o l} \cdot \mathbf{g}^{-1}\right)\end{array}$ \\
\hline Fe-R- BC & $36.20 \pm 2.96$ & $17.61 \pm 0.69$ & 27.92 & 1.10 & 8.54 & $0.23 \pm 0.03$ & $0.56 \pm 0.13$ \\
R-BC & $40.30 \pm 1.55$ & $1.31 \pm 0.08$ & 3.76 & 0.19 & 11.17 & $0.62 \pm 0.10$ & $0.53 \pm 0.13$ \\
\hline
\end{tabular}

SSA represents specific surface area (BET), TPV denotes total pore volume, APS refers to average pore size, BG is basic groups, and AG is acidic groups

Figure 1 shows the FT-IR spectra of R-BC and Fe-R-BC. The peaks around $3409 \mathrm{~cm}^{-1}$ and $3430 \mathrm{~cm}^{-1}$ were caused by the -OH (Dong et al., 2011; Samsuri et al., 2013; Xu et al., 2013; Zhang et al., 2015). The peaks at $2922 \mathrm{~cm}^{-1}$ to $2928 \mathrm{~cm}^{-1}$ can be attributed to the stretching vibration of $-\mathrm{CH}$ (Dong et al., 2011; Samsuri et al., 2013; Zhang et al., 2015). The peaks at $1612 \mathrm{~cm}^{-1}$ to $1616 \mathrm{~cm}^{-1}$ were caused by the $\mathrm{C}=\mathrm{O}$ (Garg et al., 2007; Yang et al., 2009; Tang et al., 2014; Zhang et al., 2015). The peaks at $1103 \mathrm{~cm}^{-1}$ to $1107 \mathrm{~cm}^{-1}$ were related to C-O (Dong et al., 2011; Samsuri et al., 2013; Zhang et al., 2015). The absorption peaks at $800 \mathrm{~cm}^{-1}$ to $809 \mathrm{~cm}^{-1}$ can be assigned to the aromatic compounds $=\mathrm{C}-\mathrm{H}$ (Pan et al., 2013; Samsuri et al., 2013). Compared the spectra of Fe-R-BC with that of R-BC, it can be found that the peaks of the two materials were roughly the same. The results 
indicated that the category of surface functional group of Fe-R-BC did not change. For Fe-R-BC, although the category of surface functional groups did not change, the intensity of the peak around $3409 \mathrm{~cm}^{-1}$ to $3430 \mathrm{~cm}^{-1}$ obviously increased, and the intensity of peak around $2922 \mathrm{~cm}^{-1}$ to $2928 \mathrm{~cm}^{-1}$ decreased (Figure 1). The results indicated that the hydroxyl group and methenyl group respectively increased and decreased for Fe-R-BC. The results were consistent with the changes of the number of basic and acid groups (Table 1).

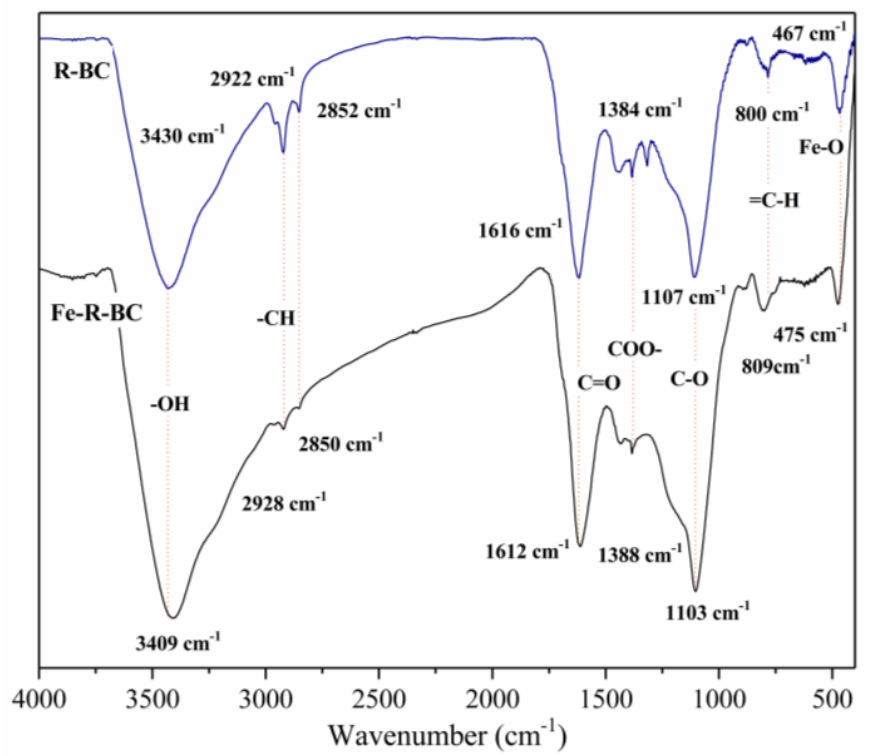

Figure 1. FT-IR spectra of $R-B C$ and $F e-R-B C$

In summary, some physicochemical properties of R-BC (i.e., specific surface area (BET), total pore volume, average pore size, and numbers of surface functional groups) were changed after modification with $\mathrm{FeCl}_{3}$. The attachment of Fe-oxides particles on the surface of R-BC and the increase of the pore structure of R-BC by the Fe-oxide particles entered the original pores of $\mathrm{R}-\mathrm{BC}$ led to the changes of basic physical properties (i.e., specific surface area and total pore volume increased, and average pore size decreased) (Wang et al., 2017). The decrease of basic groups and the increase of acidic groups indicate the acidity was increased for Fe-R-BC, which may be due to the protonationdeprotonation reaction on the surface of Fe (hydro) oxide (Sun et al., 2019). In general, the above changes of physicochemical properties of R-BC are beneficial for the $\mathrm{Cr}(\mathrm{VI})$ adsorption.

\section{Comparation of the Cr(VI) adsorption removal capacity between $R-B C$ and $F e-R-B C$}

Figure 2 shows the $\mathrm{Cr}(\mathrm{VI})$ adsorption removal rates of $\mathrm{R}-\mathrm{BC}$ and $\mathrm{Fe}-\mathrm{R}-\mathrm{BC}$ with increasing contact time. For $\mathrm{R}-\mathrm{BC}$, the $\mathrm{Cr}(\mathrm{VI})$ adsorption removal rate gradually increased and tended to equilibrium after $20 \mathrm{~h}(\mathrm{p}<0.05)$. For Fe-R-BC, the $\mathrm{Cr}(\mathrm{VI})$ adsorption removal rate rapidly increased to $93.59 \%$ at $6 \mathrm{~h}(\mathrm{p}<0.05)$, and then slowly increased $(\mathrm{p}<0.05)$ to a stable value $(\mathrm{p}>0.05)$. The maximum $\mathrm{Cr}(\mathrm{VI})$ adsorption removal rate of Fe-R-BC $(97.13 \%$, at $24 \mathrm{~h})$ was 1.73 times than that of R-BC (56.01\% at $24 \mathrm{~h})$. In general, the results indicated that the $\mathrm{Cr}(\mathrm{VI})$ adsorption removal capacity of $\mathrm{Fe}-\mathrm{R}-\mathrm{BC}$ was 
higher than that of R-BC. The results can be attributed to the following reasons: (1) Fe-R-BC had higher specific surface area (BET) and total pore volume. (2) The surface of Fe-R-BC had the more adsorption sites for $\mathrm{Cr}(\mathrm{VI})$, owing to the more acidic groups on the surface of Fe-R-BC (Liu et al., 2010). (3) The Fe oxides formed on the surface of FeR-BC had the good selectivity and affinity to Cr(VI) (Tzou et al., 2003).

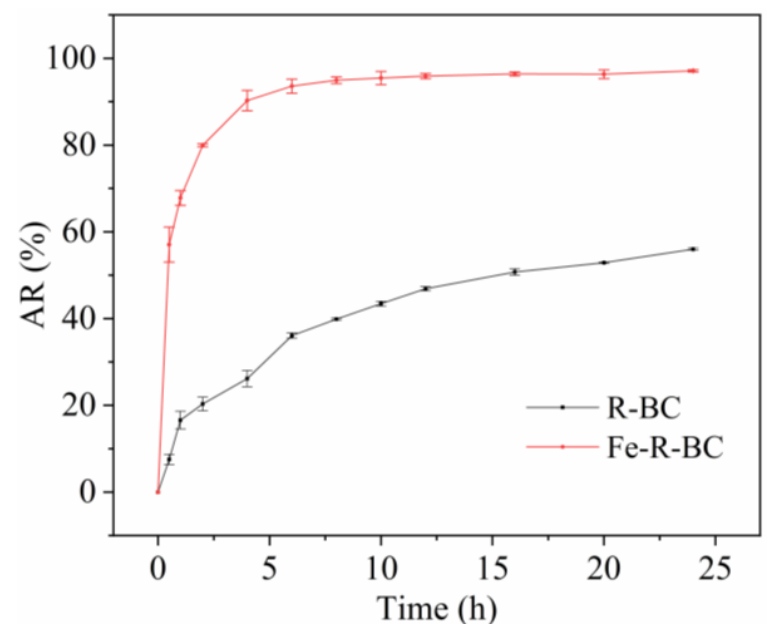

Figure 2. $C r(V I)$ adsorption removal rates of $R-B C$ and $F e-R-B C$ with increasing contact time

\section{Adsorption kinetics}

Figure 3 displays the $\mathrm{Cr}(\mathrm{VI})$ adsorption kinetics data of Fe-R-BC. There were three different adsorption removal stages in Figure 3, i.e., the rapid increasing stage $(0-6 \mathrm{~h})$ $(p<0.05)$, the slow increasing stage $(6-16 h)(p<0.05)$, and the equilibrium stage $(16-24 \mathrm{~h})$ (p>0.05). The rapid increasing stage was due to the abundant adsorption sites on the surface of Fe-R-BC in the beginning of experiment, and the slow increasing stage was owing to the decrease of the available surface adsorption sites with the prolongation of experimental time, while the equilibrium stage was related to the adsorption saturation of the surface adsorption sites (Deveci and Kar, 2013; Kaveeshwar et al., 2018).

The fitting results of the adsorption kinetic data by the pseudo first order model, the pseudo second order model, and the intraparticle diffusion model are also displayed in Figure 3. The corresponding fitting parameters are listed in Table 2. Figure 3 shows that the pseudo first order model and intraparticle diffusion model could not fit the $\mathrm{Cr}(\mathrm{VI})$ adsorption kinetics data of Fe-R-BC very well. The results were also verified by the $\mathrm{R}^{2}$ values (square of correlation coefficient) in Table 2. Compared with the above two models, the pseudo second order model acquired a higher $\mathrm{R}^{2}$ value (0.997). Moreover, the $\mathrm{q}_{\mathrm{e}}$ value (adsorption removal amount at equilibrium) acquired by fitting with the pseudo second order model was $49.46 \mathrm{mg} \cdot \mathrm{g}^{-1}$ (Table 2), which was consistent with the experimental result $\left(48.57 \mathrm{mg} \cdot \mathrm{g}^{-1}\right)$ (Figure 3). The results indicated that the $\mathrm{Cr}(\mathrm{VI})$ adsorption kinetics process of Fe-R-BC can be well described by the pseudo second order model. For the pseudo second order model, adsorption process is controlled by chemical adsorption (Mohan et al., 2011). Thus, the rate-limiting step of $\mathrm{Cr}(\mathrm{VI})$ adsorption removal by $\mathrm{Fe}-\mathrm{R}-\mathrm{BC}$ was the chemical adsorption process. For the $\mathrm{Cr}(\mathrm{VI})$ adsorption removal, the most dominant mechanism is the reduction of $\mathrm{Cr}$ (VI) to $\mathrm{Cr}$ (III) on the surface of adsorbent (Saha et al., 2010). Figure 3 also gives the Cr(III) concentration in the experiment. It can be found that the $\mathrm{Cr}(\mathrm{III})$ concentration gradually increased $(\mathrm{p}<0.05)$ and finally 
maintained equilibrium after $6 \mathrm{~h}(\mathrm{p}>0.05)$, and the change trend of $\mathrm{Cr}(\mathrm{III})$ concentration was consistent with that of $\mathrm{Cr}(\mathrm{VI})$ adsorption removal amount $\left(\mathrm{q}_{\mathrm{t}}\right)$. The results verified that the reduction of $\mathrm{Cr}(\mathrm{VI})$ to $\mathrm{Cr}(\mathrm{III})$ did happened during the $\mathrm{Cr}(\mathrm{VI})$ adsorption removal process. According to the results, it can be deduced that the reduction of $\mathrm{Cr}$ (VI) to $\mathrm{Cr}$ (III) is maybe a main chemical reaction which controlled the $\mathrm{Cr}(\mathrm{VI})$ adsorption removal process of Fe-R-BC.

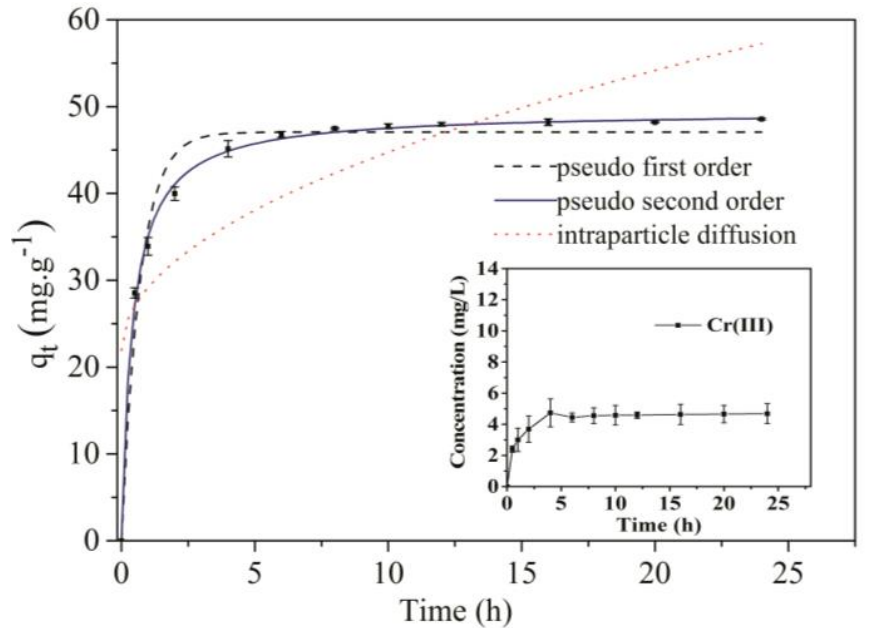

Figure 3. Kinetics data, fitted models and $\mathrm{Cr}(\mathrm{III})$ concentration of $\mathrm{Cr}(\mathrm{VI})$ adsorption removal by $\mathrm{Fe}-\mathrm{R}-\mathrm{BC}$

Table 2. Fitting parameters for the pseudo first order model, the pseudo second order model and intraparticle diffusion model

\begin{tabular}{c|c|c|c|c|c|c|c|c}
\hline \multicolumn{4}{c|}{ Pseudo first order } & \multicolumn{3}{c|}{ Pseudo second order } & \multicolumn{3}{c}{ Intraparticle diffusion model } \\
\hline $\begin{array}{c}\mathrm{q}_{\mathrm{e}} \\
\left(\mathrm{mg} \cdot \mathrm{g}^{-1}\right)\end{array}$ & $\begin{array}{c}\mathrm{k}_{1} \\
\left(\mathrm{~h}^{-1}\right)\end{array}$ & $\mathrm{R}^{2}$ & $\begin{array}{c}\mathrm{q}_{\mathrm{e}} \\
\left(\mathrm{mg} \cdot \mathrm{g}^{-1}\right)\end{array}$ & $\begin{array}{c}\mathrm{k}_{2} \\
\left(\mathrm{~g} \cdot \mathrm{mg}^{-1} \cdot \mathrm{h}^{-1}\right)\end{array}$ & $\mathrm{R}^{2}$ & $\begin{array}{c}\mathrm{C} \\
\left(\mathrm{mg} \cdot \mathrm{g}^{-1}\right)\end{array}$ & $\begin{array}{c}\mathrm{k}_{3} \\
\left(\mathrm{mg} \cdot \mathrm{g}^{-1} \cdot \mathrm{h}^{-1 / 2}\right)\end{array}$ & $\mathrm{R}^{2}$ \\
\hline 47.05 & 1.29 & 0.948 & 49.46 & 0.049 & 0.997 & 21.95 & 7.20 & 0.579 \\
\hline
\end{tabular}

\section{Adsorption isotherms}

The $\mathrm{Cr}(\mathrm{VI})$ adsorption isotherms of Fe-R-BC at three different temperatures $(283 \mathrm{~K}$, $298 \mathrm{~K}$, and $313 \mathrm{~K}$ ) are displayed in Figure 4. Generally speaking, for the all three adsorption isotherms, the $\mathrm{Cr}(\mathrm{VI})$ equilibrium adsorption removal amount $\left(\mathrm{q}_{\mathrm{e}}\right)$ rapidly increased at first $(\mathrm{p}<0.05)$, and then gradually approached to the maximum equilibrium adsorption removal amount $(p>0.05)$ with the increase of equilibrium concentration $\left(C_{e}\right)$.

The fitted results of adsorption isotherms by the Freundlich isotherm model, the Langmuir isotherm model, and the Langmuir-Freundlich isotherm model are presented in Figure 4. Table 3 lists the corresponding model parameters. At all temperatures, the adsorption isotherms fitted with the Langmuir-Freundlich isotherm model were closer to the experimental data (Figure 4). Furthermore, compared to those of other two isotherm models, the $\mathrm{R}^{2}$ values (square of correlation coefficient) of Langmuir-Freundlich isotherm model $\left(\mathrm{R}^{2}=0.998,0.999\right.$, and 0.990 at $283 \mathrm{~K}, 298 \mathrm{~K}$, and $313 \mathrm{~K}$, respectively) (Table 3) were the largest. The results illuminated that the $\mathrm{Cr}(\mathrm{VI})$ adsorption isotherms of Fe-R-BC can be better explained by the Langmuir-Freundlich isotherm model. The 
conclusion means that the $\mathrm{Cr}(\mathrm{VI})$ adsorption removal by Fe-R-BC belongs to the multimolecular layer adsorption, which is regulated by multiple processes due to the heterogeneity of Fe-R-BC (Liu et al., 2010; Jung et al., 2015).

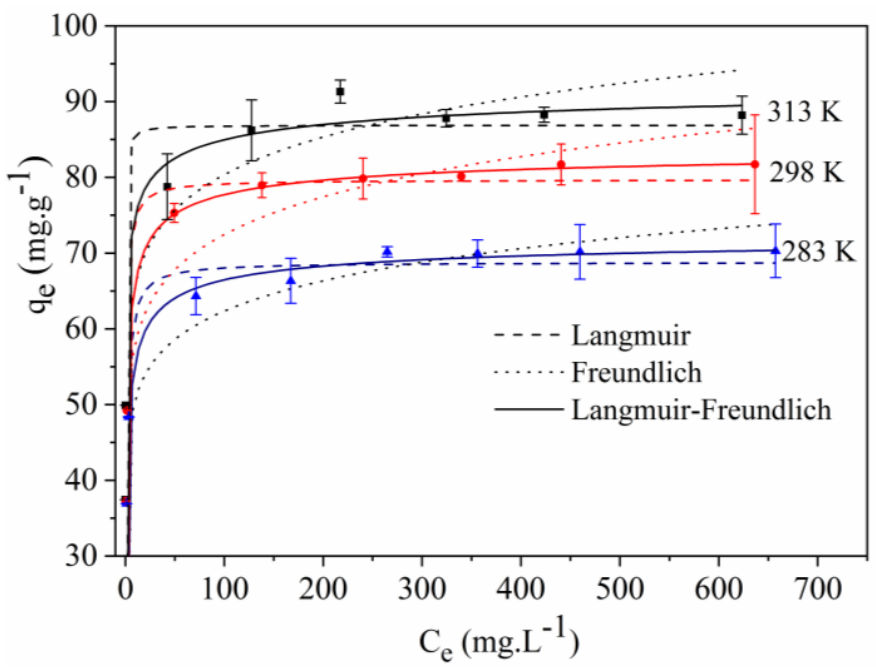

Figure 4. Isotherms and fitted models of $C r(V I)$ adsorption removal by $\mathrm{Fe}-\mathrm{R}-\mathrm{BC}$ at three different temperatures

Table 3. Fitting parameters for the Freundlich isotherm model, the Langmuir isotherm model and the Langmuir-Freundlich isotherm model

\begin{tabular}{c|c|c|c|c|c|c|c|c|c|c}
\hline \multirow{2}{*}{$\mathbf{T}(\mathbf{K})$} & \multicolumn{3}{|c|}{ Langmuir model } & \multicolumn{3}{c|}{ Freundlich model } & \multicolumn{3}{c}{ Langmuir-Freundlich model } \\
\cline { 2 - 10 } & $\begin{array}{c}\mathrm{q}_{\mathrm{m}} \\
\left(\mathrm{mg} \cdot \mathrm{g}^{-1}\right)\end{array}$ & $\begin{array}{c}\mathrm{K}_{\mathrm{L}} \\
\left(\mathrm{L} \cdot \mathrm{mg}^{-1}\right)\end{array}$ & $\mathrm{R}^{2}$ & $\begin{array}{c}\mathrm{K}_{\mathrm{F}} \\
\left(\mathrm{mg} \cdot \mathrm{g}^{-1}\right) \\
\left(\mathrm{L} \cdot \mathrm{mg}^{-1}\right)^{1 / n}\end{array}$ & $1 / \mathrm{n}$ & $\mathrm{R}^{2}$ & $\begin{array}{c}\mathrm{q}_{\mathrm{m}} \\
\left(\mathrm{mg} \cdot \mathrm{g}^{-1}\right)\end{array}$ & $\begin{array}{c}\mathrm{K} \\
\left(\mathrm{L}^{\mathrm{mg}} \mathrm{m}^{-1}\right)\end{array}$ & $1 / \mathrm{n}$ & $\mathrm{R}^{2}$ \\
\hline 283 & 68.81 & 0.86 & 0.991 & 41.25 & 0.090 & 0.983 & 73.04 & 0.99 & 0.505 & 0.998 \\
298 & 79.68 & 1.41 & 0.986 & 46.60 & 0.095 & 0.975 & 84.68 & 1.12 & 0.498 & 0.999 \\
313 & 86.88 & 6.51 & 0.988 & 53.89 & 0.089 & 0.976 & 94.95 & 1.64 & 0.358 & 0.990 \\
\hline
\end{tabular}

According to the previous report (Tseng and $\mathrm{Wu}, 2008$ ), the favorable degree of an adsorption reaction can be divided to five levels based on the value of heterogeneity factor $(1 / \mathrm{n})$, namely, $1 / \mathrm{n}<0.01$ : the pseudo-irreversible level, $0.01<1 / \mathrm{n}<0.1$ : the strong favorable level, $0.1<1 / \mathrm{n}<0.5$ : the favorable level, $0.5<1 / \mathrm{n}<1$ : the pseudo-linear level, and $1 / \mathrm{n}>1$ : the unfavorable level. According to the values of $1 / \mathrm{n}$ (Table 3), the favorable degree of $\mathrm{Cr}(\mathrm{VI})$ adsorption removal by $\mathrm{Fe}-\mathrm{R}-\mathrm{BC}$ at $283 \mathrm{~K}$ belonged to the pseudo-linear level, whereas the favorable degree of $\mathrm{Cr}(\mathrm{VI})$ adsorption removal by Fe-R-BC at $298 \mathrm{~K}$ and $313 \mathrm{~K}$ can be classified as the favorable level. For the constant $\mathrm{K}$ (Table 3), the value was positively correlated with temperature, which indicated that the adsorption removal capacity of $\mathrm{Fe}-\mathrm{R}-\mathrm{BC}$ for $\mathrm{Cr}(\mathrm{VI})$ is enhanced with increasing temperature (Jung et al., 2015). For $\mathrm{q}_{\mathrm{m}}$ (Table 3), the value calculated from the Langmuir-Freundlich model was respectively $73.04 \mathrm{mg} \cdot \mathrm{g}^{-1}, 84.68 \mathrm{mg} \cdot \mathrm{g}^{-1}$, and $94.95 \mathrm{mg} \cdot \mathrm{g}^{-1}$ at $283 \mathrm{~K}, 298 \mathrm{~K}$, and $313 \mathrm{~K}$, which was unanimous with our experiment results $\left(71.29 \mathrm{mg} \cdot \mathrm{g}^{-1}, 81.73 \mathrm{mg} \cdot \mathrm{g}^{-1}\right.$, $88.19 \mathrm{mg} \cdot \mathrm{g}^{-1}$ at $283 \mathrm{~K}, 298 \mathrm{~K}$, and $313 \mathrm{~K}$, respectively). 
Compared with some previous reported carbon materials for the $\mathrm{Cr}(\mathrm{VI})$ adsorption removal (Table 4), Fe-R-BC had a relatively high $\mathrm{Cr}(\mathrm{VI})$ adsorption removal capacity. Furthermore, as the raw materials (i.e., rice straw and $\mathrm{FeCl}_{3}$ ) have the properties of low cost and extensive sources, Fe-R-BC is economical. Moreover, the pyrolysis temperature was $673 \mathrm{~K}$, which was much lower than that of activated carbon (Giri et al., 2012; Nethaji et al., 2013). Therefore the preparation of Fe-R-BC had low energy consumption advantage. In addition, for the modification, only one-time immersion is used. Thereform, the preparation process was relatively simple. In view of the above advantages, Fe-R-BC has the great potential of application for $\mathrm{Cr}(\mathrm{VI})$ adsorption removal.

Table 4. Comparison of the maximum Cr(VI) adsorption removal capacity with those of some previous reported carbon materials

\begin{tabular}{|c|c|c|}
\hline Adsorbents & $\underset{\left(\mathbf{m g} \cdot \mathbf{g}^{-1}\right)}{\mathbf{q}}$ & $\begin{array}{l}\text { Temperature } \\
(\mathbf{K})\end{array}$ \\
\hline $\begin{array}{l}\text { Fe-modified activated carbon prepared from Trapanatans husk (Liu et al., } \\
\text { 2010) }\end{array}$ & 18.66 & 313 \\
\hline Polyethylenimine modified biochar (Ma et al., 2014) & 435.7 & / \\
\hline $\begin{array}{c}\text { Chitosan modification of magnetic biochar produced from } \\
\text { Eichhorniacrassipes (Zhang et al., 2015) }\end{array}$ & 167.31 & 313 \\
\hline $\begin{array}{l}\text { Biochar from the blends of oily seeds of } P \text {. terebinthus } L \text {. with alumina } \\
\text { (Deveci and Kar, 2013) }\end{array}$ & 6.08 & / \\
\hline $\begin{array}{l}\text { Activated carbon derived from Eichhorniacrassipes root biomass (Giri et } \\
\text { al., 2012) }\end{array}$ & 36.34 & 298 \\
\hline Mycelial pellets impregnated with powdered biochar (Xu et al., 2015) & 28.00 & 301 \\
\hline $\begin{array}{l}\text { corn cob activated carbon coated with nano-sized magnetite particles } \\
\text { (Nethaji et al., 2013) }\end{array}$ & 57.37 & 300 \\
\hline $\mathrm{Fe}-\mathrm{R}-\mathrm{BC}$ & 94.95 & 313 \\
\hline
\end{tabular}

\section{Thermodynamic analysis}

To better understand the $\mathrm{Cr}(\mathrm{VI})$ adsorption removal process of $\mathrm{Fe}-\mathrm{R}-\mathrm{BC}$, the thermodynamic analysis was performed. Table 5 lists the calculated values of $\Delta \mathrm{G}^{0}, \Delta \mathrm{H}^{0}$, and $\Delta \mathrm{S}^{0}$ for the $\mathrm{Cr}(\mathrm{VI})$ adsorption removal by Fe-R-BC. The value of $\Delta \mathrm{G}^{0}$ was $-2.05 \mathrm{~kJ} \cdot \mathrm{mol}^{-1},-2.76 \mathrm{~kJ} \cdot \mathrm{mol}^{-1},-3.54 \mathrm{~kJ} \cdot \mathrm{mol}^{-1}$ at $283 \mathrm{~K}, 298 \mathrm{~K}, 313 \mathrm{~K}$, respectively. On the one hand, the values of $\Delta \mathrm{G}^{0}$ were always negative at different temperatures, which manifested that the $\mathrm{Cr}(\mathrm{VI})$ adsorption removal process of $\mathrm{Fe}-\mathrm{R}-\mathrm{BC}$ was spontaneous (Tan et al., 2015). On the other hand, the value of $\Delta \mathrm{G}^{0}$ presented a negative correlation with temperature (i.e., the $\Delta \mathrm{G}^{0}$ value decreased as the temperature increased), which indicated that high temperature is favorable for $\mathrm{Cr}(\mathrm{VI})$ adsorption removal by $\mathrm{Fe}-\mathrm{R}-\mathrm{BC}$. The $\Delta \mathrm{H}^{0}$ and $\Delta \mathrm{S}^{0}$ value was $0.0058 \mathrm{~kJ} \cdot \mathrm{mol}^{-1}$ and $0.034 \mathrm{~kJ} \cdot \mathrm{mol}^{-1} \cdot \mathrm{K}^{-1}$, respectively. The positive value of $\Delta \mathrm{H}^{0}$ and $\Delta \mathrm{S}^{0}$ implied that the $\mathrm{Cr}(\mathrm{VI})$ adsorption removal by $\mathrm{Fe}-\mathrm{R}-\mathrm{BC}$ is an endothermic process and the randomness at Fe-R-BC-solution interface has the increasing trend during the adsorption process (Siddiqui et al., 2016).

\section{Effect of initial solution pH on the Cr(VI) adsorption removal}

The effect of initial solution $\mathrm{pH}$ on the $\mathrm{Cr}(\mathrm{VI})$ adsorption removal by Fe-R-BC is shown in Figure 5. It can be found that the initial solution $\mathrm{pH}$ obviously influenced the $\mathrm{Cr}(\mathrm{VI})$ adsorption removal by Fe-R-BC ( $\mathrm{p}<0.05)$. The maximum and minimum $\mathrm{Cr}(\mathrm{VI})$ adsorption removal rate was $97.13 \%$ and $7.81 \%$, respectively. With decreasing $\mathrm{pH}$, the 
$\mathrm{Cr}(\mathrm{VI})$ adsorption removal rate presented an increasing tendency in Figure 5. The result was in accordance with the previous studies (Liu et al., 2010; Ma et al., 2014; Wu et al., 2017). For $\mathrm{Cr}(\mathrm{VI})$, it can present as the forms of $\mathrm{HCrO}_{4}{ }^{-}, \mathrm{CrO}_{4}{ }^{2-}$ and $\mathrm{Cr}_{2} \mathrm{O}_{7}{ }^{2-}$ in aqueous solutions. At low $\mathrm{pH}(2<\mathrm{pH}<3), \mathrm{HCrO}_{4}^{-}$is the primary form of $\mathrm{Cr}(\mathrm{VI})$. However, the primary form gradually shifts to $\mathrm{CrO}_{4}{ }^{2-}$ and $\mathrm{Cr}_{2} \mathrm{O}_{7}{ }^{2-}$ as $\mathrm{pH}$ increases. Compared with $\mathrm{CrO}_{4}{ }^{2-}$ and $\mathrm{Cr}_{2} \mathrm{O}_{7}{ }^{2-}$, the adsorption of $\mathrm{HCrO}_{4}{ }^{-}$is easier and more rapid due to its requirement of only one adsorption site (Kuppusamy et al., 2016). Thus, the $\mathrm{Cr}(\mathrm{VI})$ adsorption removal efficiency of Fe-R-BC increased as $\mathrm{pH}$ decreased. Furthermore, the surface charge of adsorbent significantly influences the $\mathrm{Cr}(\mathrm{VI})$ adsorption removal efficiency (Zhao et al., 2017). For Fe-R-BC, Figure 5 also displays the change of zeta potential with the variation of $\mathrm{pH}$. The point of zero charge $\left(\mathrm{pH}_{\mathrm{zpc}}\right)$ of $\mathrm{Fe}-\mathrm{R}-\mathrm{BC}$ was obtained from the change of zeta potential. For Fe-R-BC, the $\mathrm{pH}_{\mathrm{zpc}}$ was 2.79. That is to say, the surface charge of Fe-R-BC was positive when the solution $\mathrm{pH}<2.79$, whereas the surface charge of Fe-R-BC was negative when the solution $\mathrm{pH}>2.79$. The positive surface charge of Fe-R-BC in the solution $\mathrm{pH}<2.79$ could promote the positive-negative charge attraction, thus it is beneficial for the $\mathrm{Cr}(\mathrm{VI})$ adsorption (Zhao et al., 2017). This may be the other reason for the high $\mathrm{Cr}(\mathrm{VI})$ adsorption efficiency of $\mathrm{Fe}-\mathrm{R}-\mathrm{BC}$ under the low $\mathrm{pH}$ conditions, especially at $\mathrm{pH}=2$.

Table 5. Values of Gibbs free energy, enthalpy, and entropy

\begin{tabular}{c|c|c|c|c}
\hline \multicolumn{3}{c|}{$\Delta \mathbf{G}^{\mathbf{0}}\left(\mathbf{k J} \cdot \mathbf{m o l}^{\mathbf{1}}\right)$} & $\Delta \mathbf{H}^{\mathbf{0}}\left(\mathbf{k J} \cdot \mathbf{m o l}^{\mathbf{- 1}}\right)$ & $\Delta \mathbf{S}^{\mathbf{0}}\left(\mathbf{k J} \cdot \mathbf{m o l}^{\mathbf{- 1}} \cdot \mathbf{K}^{\mathbf{1}}\right)$ \\
\hline $283 \mathrm{~K}$ & $298 \mathrm{~K}$ & $313 \mathrm{~K}$ & 0.0058 & 0.034 \\
\hline-2.05 & -2.76 & -3.54 & & 0 \\
\hline
\end{tabular}

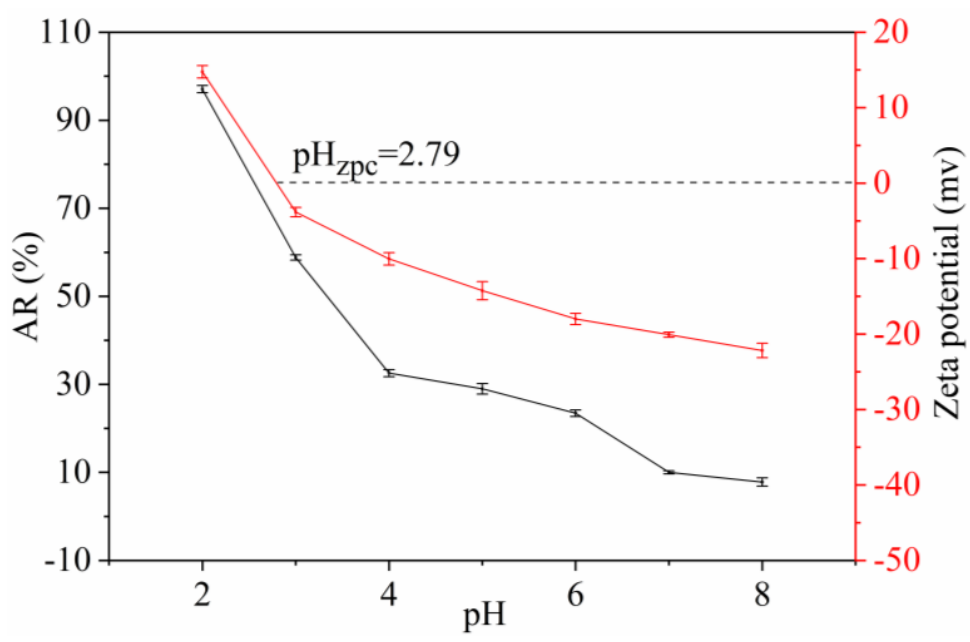

Figure 5. Effect of initial solution $p H$ on the $C r(V I)$ adsorption removal by $\mathrm{Fe}-\mathrm{R}-\mathrm{BC}$ and Zeta potentials of $\mathrm{Fe}-\mathrm{R}-\mathrm{BC}$ at different $\mathrm{pH}$

\section{Effect of coexisting ions on $\mathrm{Cr}(\mathrm{VI})$ adsorption removal}

Figure 6 shows the effects of three coexisting ions (i.e., $\mathrm{Cl}^{-}, \mathrm{NO}_{3}{ }^{-}$, and $\mathrm{SO}_{4}{ }^{2-}$ ) on the $\mathrm{Cr}(\mathrm{VI})$ adsorption removal by $\mathrm{Fe}-\mathrm{R}-\mathrm{BC}$. The $\mathrm{Cr}(\mathrm{VI})$ adsorption removal rate of $\mathrm{Fe}-\mathrm{R}-\mathrm{BC}$ decreased with increasing the concentrations of three coexisting ions $(\mathrm{p}<0.05) . \mathrm{Cl}^{-}, \mathrm{NO}_{3}{ }^{-}$ and $\mathrm{SO}_{4}{ }^{2-}$ respectively resulted in $20.65 \%, 28.82 \%$, and $35.89 \%$ reduction of the $\mathrm{Cr}(\mathrm{VI})$ 
adsorption removal rate with the increase of their concentrations from $0 \mathrm{M}$ to $2.0 \mathrm{M}$. The results showed that the three coexisting ions can affect the $\mathrm{Cr}(\mathrm{VI})$ adsorption removal by $\mathrm{Fe}-\mathrm{R}-\mathrm{BC}$, but the influence degrees of the three coexisting ions were different. Under the same condition of ion concentration, $\mathrm{SO}_{4}{ }^{2-}$ had the strongest effect on the $\mathrm{Cr}(\mathrm{VI})$ adsorption removal by Fe-R-BC, followed by $\mathrm{NO}_{3}{ }^{-}$and $\mathrm{Cl}^{-}$. For the three coexisting ions, the reduction of $\mathrm{Cr}(\mathrm{VI})$ adsorption removal rate with the increase of ion concentration could be attribute to the decreasing activity of $\mathrm{Cr}(\mathrm{VI})$ in solution with increasing the ion concentration (Zhang et al., 2013). However, the different influence degrees on the $\mathrm{Cr}(\mathrm{VI})$ adsorption removal might be related to the different adsorption competitiveness of the three coexisting ions with $\mathrm{Cr}(\mathrm{VI})$. For $\mathrm{SO}_{4}{ }^{2-}$, it was a polyvalent anion with semblable structure and size to $\mathrm{HCrO}_{4}^{-}, \mathrm{CrO}_{7}^{2-}$, and $\mathrm{CrO}_{4}{ }^{2-}$, thus it had the strong adsorption competitiveness with $\mathrm{HCrO}_{4}{ }^{-}, \mathrm{CrO}_{7}{ }^{2-}$, and $\mathrm{CrO}_{4}{ }^{2-}$ compared with $\mathrm{NO}_{3}{ }^{-}$and $\mathrm{Cl}^{-}$(Wang et al., 2017). The strong adsorption competitiveness of $\mathrm{SO}_{4}{ }^{2-}$ led to its greatest influence on the $\mathrm{Cr}(\mathrm{VI})$ adsorption removal. Based on the above results, for the practical application of Fe-R-BC to remove $\mathrm{Cr}(\mathrm{VI})$ from high salt wastewater (especially sulfate and nitrate wastewater), the wastewater should be desalinated firstly.

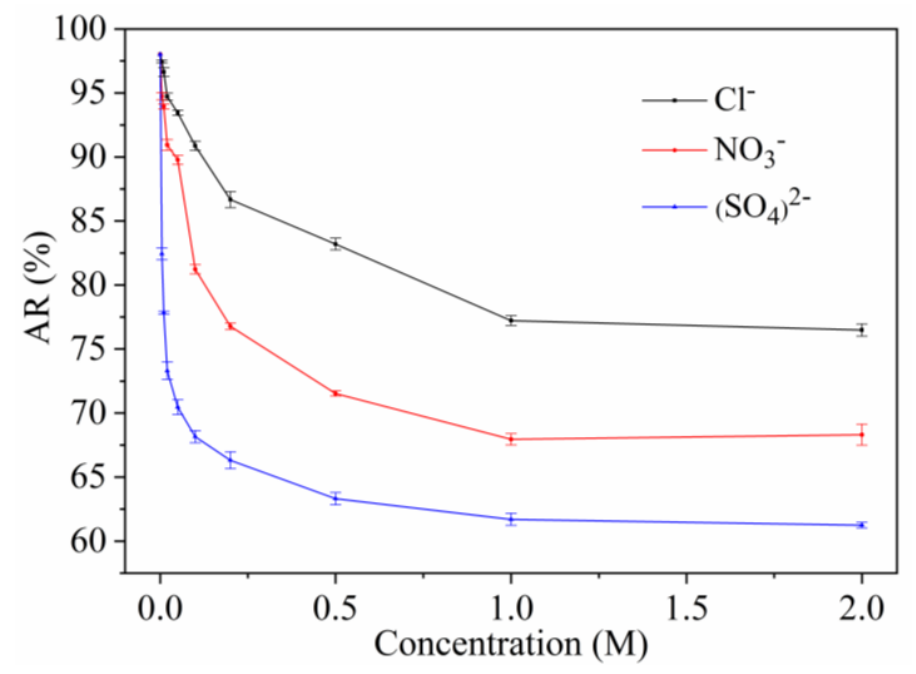

Figure 6. Influence of coexisting ions on $\mathrm{Cr}(\mathrm{VI})$ adsorption removal by $\mathrm{Fe}-\mathrm{R}-\mathrm{BC}$

\section{Regeneration of Fe-R-BC}

For the application of an adsorbent, the regenerative property of adsorbent should be considered because it determines the economic efficiency of an adsorbent. In this study, the regenerative property of Fe-R-BC was evaluated through 4 cycles of adsorptiondesorption experiment. Figure 7 shows the $\mathrm{Cr}(\mathrm{VI})$ adsorption removal rates of Fe-R-BC after experiencing different cycles of adsorption-desorption. With increasing the cycle, the $\mathrm{Cr}(\mathrm{VI})$ adsorption removal rate gradually decreased $(\mathrm{p}<0.05)$. This is a common problem for adsorbents in the cyclic utilization process. It might be owing to the quantity loss of adsorbent and the continuous damage of adsorbent structure during regeneration (Salvador et al., 2015). However, in the fourth cycle, the $\mathrm{Cr}(\mathrm{VI})$ adsorption removal rate was $75.12 \%$, which was equal to $76.27 \%$ of that of the pristine Fe-R-BC ( 0 cycle). The results indicated that Fe-R-BC had the good regenerative property, and $0.1 \mathrm{M} \mathrm{NaOH}$ solution can be used as an eluent for its regeneration. Generally speaking, the good regenerative property of $\mathrm{Fe}-\mathrm{R}-\mathrm{BC}$ is beneficial to decrease the cost of use. 


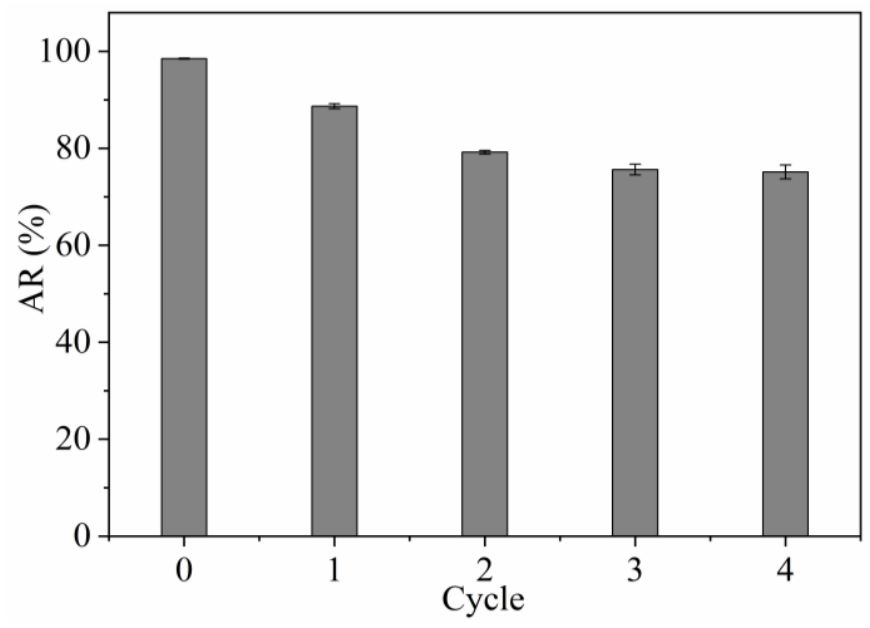

Figure 7. $C r(V I)$ adsorption removal rates of $F e-R-B C$ after experiencing different cycles of adsorption-desorption

\section{Conclusions}

Fe-R-BC was prepared from rice straw with $\mathrm{FeCl}_{3}$ modification by pyrolyzing in this study. Compared to those of R-BC, the Fe content, specific surface area (BET), total pore volume, and number of hydroxyl group of Fe-R-BC increased, while the average pore size and number of methenyl group decreased. For the $\mathrm{Cr}(\mathrm{VI})$ adsorption removal by Fe-R-BC, the adsorption kinetics data can be well described by the pseudo second order model, while the adsorption isotherms data can be well described by the LangmuirFreundlich isotherm model. For Fe-R-BC, the maximum $\mathrm{Cr}(\mathrm{VI})$ adsorption removal capacity was $94.95 \mathrm{mg} \cdot \mathrm{g}^{-1}$, which exceed those of some previous reported carbon materials. The initial solution $\mathrm{pH}$ had a significant effect on the $\mathrm{Cr}(\mathrm{VI})$ adsorption removal capacity of Fe-R-BC, which increased with decreasing the initial solution $\mathrm{pH}$. The $\mathrm{Cr}(\mathrm{VI})$ adsorption removal by Fe-R-BC was a spontaneous and endothermic process. The $\mathrm{Cr}(\mathrm{VI})$ adsorption removal capacity of Fe-R-BC decreased with increasing coexistence ion $\left(\mathrm{Cl}^{-}, \mathrm{NO}_{3}{ }^{-}\right.$, and $\left.\mathrm{SO}_{4}{ }^{2-}\right)$ concentration in solution. In addition, the influence degree of $\mathrm{Cl}^{-}, \mathrm{NO}_{3}^{-}$, and $\mathrm{SO}_{4}{ }^{2-}$ was ordered as follows: $\mathrm{SO}_{4}{ }^{2-}>\mathrm{NO}_{3}{ }^{-}>\mathrm{Cl}^{-}$. Fe-R-BC had the good regenerative property, and $0.1 \mathrm{M} \mathrm{NaOH}$ solution can be used as an eluent for the regeneration. Overall, Fe-R-BC can be applied to the treatment of wastewater containing $\mathrm{Cr}(\mathrm{VI})$. In the future, the treatment effect of $\mathrm{Fe}-\mathrm{R}-\mathrm{BC}$ for other anions needs to be further explored.

Acknowledgements. This work was supported by the Scientific Research Innovation Team Project of Sichuan Provincial Department of Education (No. 16TD0006) and the Undergraduate Training Program for Innovation and Entrepreneurship of Sichuan Agricultural University (No. 201610626042).

\section{REFERENCES}

[1] Agrafioti, E., Kalderis, D., Diamadopoulos, E. (2014): Arsenic and chromium removal from water using biochars derived from rice husk, organic solid wastes and sewage sludge. - J. Environ. Manage. 133: 309-314. 
[2] Ahmad, M., Rajapaksha, A. U., Lim, J. E., Zhang, M., Bolan, N., Mohan, D., Vithanage, M., Lee, S. S., Ok, Y. S. (2014): Biochar as a sorbent for contaminant management in soil and water: A review. - Chemosphere 99: 19-33.

[3] Baran, A., Bıçak, E., Baysal, Ş. H., Önal, S. (2007): Comparative studies on the adsorption of $\mathrm{Cr}(\mathrm{VI})$ ions on to various sorbents. - Bioresour. Technol. 98: 661-665.

[4] Chun, Y., Sheng, G., Chiou, C. T., Xing, B. (2004): Compositions and sorptive properties of crop residue-derived chars. - Environ. Sci. Technol. 38: 4649-4655.

[5] Deveci, H., Kar, Y. (2013): Adsorption of hexavalent chromium from aqueous solutions by bio-chars obtained during biomass pyrolysis. - J. Ind. Eng. Chem. 19: 190-196.

[6] Ding, Z., Hu, X., Wan, Y., Wang, S., Gao, B. (2016): Removal of lead, copper, cadmium, zinc, nickel from aqueous solutions by alkali-modified biochar: Batch and column tests. J. Ind. Eng. Chem. 33: 239-245.

[7] Dong, X., Ma, L. Q., Li, Y. (2011): Characteristics and mechanisms of hexavalent chromium removal by biochar from sugar beet tailing. - J. Hazard. Mater. 190: 909-915.

[8] Dong, L., Chang, K., Wang, L., Linghu, W., Zhao, D., Asiri, A. M., Alamry, K. A., Alsaedi, A., Hayat, T., Li, X., Wu, X. (2018): Application of biochar derived from rice straw for the removal of Th(IV) from aqueous solution. - Sep. Sci. Technol. 53: 1511-1521.

[9] Gan, C., Liu, Y., Tan, X., Wang, S., Zeng, G., Zheng, B., Li, T., Jiang, Z., Liu, W. (2015): Effect of porous Zinc-biochar nanocomposites on $\mathrm{Cr}(\mathrm{VI})$ adsorption from aqueous solution. - RSC Adv. 5: 35107-35115.

[10] Garg, U. K., Kaur, M. P., Garg, V. K., Sud, D. (2007): Removal of hexavalent chromium from aqueous solution by agricultural waste biomass. - J. Hazard. Mater. 140: 60-68.

[11] Giannakoudakis, D. A., Kyzas, G. Z., Avranas, A., Lazaridis, N. K. (2016): Multiparametric adsorption effects of the reactive dye removal with commercial activated carbons. - J. Mol. Liq. 213: 381-389.

[12] Giri, A. K., Patel, R., Mandal, S. (2012): Removal of Cr (VI) from aqueous solution by Eichhornia crassipes root biomass-derived activated carbon. - Chem. Eng. J. 185-186: 7181.

[13] Golder, A. K., Chanda, A. K., Samanta, A. N., Ray, S. (2011): Removal of hexavalent chromium by electrochemical reduction and ash precipitation: Investigation of process performance and reaction stoichiometry. - Sep. Purif. Technol. 76: 345-350.

[14] Gu, Z., Fang, J., Deng, B. (2005): Preparation and evaluation of GAC-based ironcontaining adsorbents for arsenic removal. - Environ. Sci. Technol. 39: 3833-3843.

[15] Gupta, V. K., Nayak, A., Agarwal, S. (2015): Bioadsorbents for remediation of heavy metals: Current status and their future prospects. - Environ. Eng. Res. 20: 1-18.

[16] Han, X., Liang, C., Li, T., Wang, K., Huang, H., Yang, X. (2013): Simultaneous removal of cadmium and sulfamethoxazole from aqueous solution by rice straw biochar. $-\mathrm{J}$. Zhejiang Univ.-SCI. B. 14: 640-649.

[17] Inyang, M. I., Gao, B., Yao, Y., Xue, Y., Zimmerman, A., Mosa, A., Pullammanappallil, P., Ok, Y. S., Cao, X. (2016): A review of biochar as a low-cost adsorbent for aqueous heavy metal removal. - Crit. Rev. Environ. Sci. Technol. 46: 406-433.

[18] Jiang, J., Peng, Y., Yuan, M., Hong, Z., Wang, D., Xu, R. (2015): Rice straw-derived biochar properties and functions as $\mathrm{Cu}(\mathrm{II})$ and cyromazine sorbents as influenced by pyrolysis temperature. - Pedosphere 25: 781-789.

[19] Jung, K. W., Hwang, M. J., Jeong, T. U., Ahn, K. H. (2015): A novel approach for preparation of modified-biochar derived from marine macroalgae: Dual purpose electromodification for improvement of surface area and metal impregnation. - Bioresour. Technol. 191: 342-345.

[20] Kaveeshwar, A. R., Ponnusamy, S. K., Revellame, E. D., Gang, D. D., Zappi1, M. E., Subramaniam, R. (2018): Pecan shell based activated carbon for removal of iron(II) from fracking wastewater: Adsorption kinetics, isotherm and thermodynamic studies. - Process Saf. Environ. Prot. 114: 107-122. 
[21] Kuppusamy, S., Thavamani, P., Megharaj, M., Venkateswarlu, K., Lee, Y. B., Naidu, R. (2016): Oak (Quercus robur) Acorn Peel as a low-cost adsorbent for hexavalent chromium removal from aquatic ecosystems and industrial effluents. - Water Air Soil Pollut. 227: 62.

[22] Liu, W., Zhang, J., Zhang, C., Wang, Y., Li, Y. (2010): Adsorptive removal of Cr (VI) by Fe-modified activated carbon prepared from trapa natans husk. - Chem. Eng. J. 162: 677684.

[23] Ma, Y., Liu, W. J., Zhang, N., Li, Y. S., Jiang, H., Sheng, G. P. (2014): Polyethylenimine modified biochar adsorbent for hexavalent chromium removal from the aqueous solution. - Bioresour. Technol. 169: 403-408.

[24] Mella, B., Glanert, A. C., Gutterres, M. (2015): Removal of chromium from tanning wastewater and its reuse. - Process Saf. Environ. 95: 195-201.

[25] Mohan, D., Rajput, S., Singh, V. K., Steele, P. H., Pittman, C. U. (2011): Modeling and evaluation of chromium remediation from water using low cost bio-char, a green adsorbent. - J. Hazard. Mater. 188: 319-333.

[26] Nethaji, S., Sivasamy, A., Mandal, A. B. (2013): Preparation and characterization of corn cob activated carbon coated with nano-sized magnetite particles for the removal of $\mathrm{Cr}(\mathrm{VI})$. - Bioresour. Technol. 134: 94-100.

[27] Pan, J., Jiang, J., Xu, R. (2013): Adsorption of Cr(III) from acidic solutions by crop straw derived biochars. - J. Environ. Sci. 25: 1957-1965.

[28] Park, J. H., Ok, Y. S., Kim, S. H., Cho, J. S., Heo, J. S., Delaune, R. D., Seo, D. C. (2016a): Competitive adsorption of heavy metals onto sesame straw biochar in aqueous solutions. Chemosphere 142: 77-83.

[29] Park, S. H., Cho, H. J., Ryu, C., Park, Y. K. (2016b): Removal of copper(II) in aqueous solution using pyrolytic biochars derived from red macroalga Porphyra tenera. - J. Ind. Eng. Chem. 36: 314-319.

[30] Park, J. H., Wang, J. J., Kim, S. H., Cho, J. S., Kang, S. W., Delaune, R. D., Han, K. J., Seo, D. C. (2017): Recycling of rice straw through pyrolysis and its adsorption behaviors for $\mathrm{Cu}$ and $\mathrm{Zn}$ ions in aqueous solution. - Colloid Surf. A-Physicochem. Eng. Asp. 533: 330-337.

[31] Rafati, L., Mahvi, A. H., Asgari, A. R., Hosseini, S. S. (2010): Removal of chromium (VI) from aqueous solutions using Lewatit FO 36 nano ion exchange resin. - Int. J. Environ. Sci. Technol. 7: 147-156.

[32] Rajapaksha, A. U., Chen, S. S., Tsang, D. C. W., Zhang, M., Vithanage, M., Mandal, S., Gao, B., Bolan, N. S., Ok, Y. S. (2016): Engineered/designer biochar for contaminant removal/immobilization from soil and water: Potential and implication of biochar modification. - Chemosphere 148: 276-291.

[33] Saha, B., Orvig, C. (2010): Biosorbents for hexavalent chromium elimination for industrial and municipal effluents. - Coord. Chem. Rev. 254: 2959-2972.

[34] Salvador, F., Martin-Sanchez, N., Sanchez-Hernandez, R., Sanchez-Montero, M. J., Izquierdo, C. (2015): Regeneration of carbonaceous adsorbents. Part I: Thermal Regeneration. - Microporous Mesoporous Mat. 202: 259-276.

[35] Samsuri, A. W., Sadegh-Zadeh, F., Seh-Bardan, B. J. (2013): Adsorption of As(III) and $\mathrm{As}(\mathrm{V})$ by Fe coated biochars and biochars produced from empty fruit bunch and rice husk. - J. Environ. Chem. Eng. 1: 981-988.

[36] Siddiqui, S. H., Ahmad, R. (2017): Pistachio Shell Carbon (PSC) - an agricultural adsorbent for the removal of $\mathrm{Pb}$ (II) from aqueous solution. - Groundw. Sustain. Dev. 4: 42-48.

[37] Soylak, M., Divrikli, U., Saracoglu, S., Elci, L. (2007): Membrane filtration-atomic absorption spectrometry combination for copper, cobalt, cadmium, lead and chromium in environmental samples. - Environ. Monit. Assess. 127: 169-176.

[38] Sun, Y., Yu, I. K. M., Tsang, D. C. W., Cao, X., Lin, D., Wang, L., Graham, N. J. D., Alessi, D. S., Komárek, M., Ok, Y. S., Feng, Y., Li, X. D. (2019): Multifunctional ironbiochar composites for the removal of potentially toxic elements, inherent cations, and hetero-chloride from hydraulic fracturing wastewater. - Environ. Int. 124: 521-532. 
[39] Tan, X., Liu, Y., Zeng, G., Wang, X., Hu, X., Gu, Y., Yang, Z. (2015): Application of biochar for the removal of pollutants from aqueous solutions. - Chemosphere 125: 70-85.

[40] Tang, L., Yang, G. D., Zeng, G. M., Cai, Y., Li, S. S., Zhou, Y. Y., Pang, Y., Liu, Y. Y., Zhang, Y., Luna, B. (2014): Synergistic effect of iron doped ordered mesoporous carbon on adsorption-coupled reduction of hexavalent chromium and the relative mechanism study. - Chem. Eng. J. 239: 114-122.

[41] Tseng, R. L., Wu, F. C. (2008): Inferring the favorable adsorption level and the concurrent multi-stage process with the Freundlich constant. - J. Hazard. Mater. 155: 277-287.

[42] Tzou, Y. M., Wang, M. K., Loeppert, R. H. (2003): Sorption of phosphate and Cr(VI) by $\mathrm{Fe}(\mathrm{III})$ and $\mathrm{Cr}(\mathrm{III})$ hydroxides. - Arch. Environ. Contam. Toxicol. 44: 445-453.

[43] Uddin, M. K. (2017): A review on the adsorption of heavy metals by clay minerals, with special focus on the past decade. - Chem. Eng. J. 308: 438-462.

[44] Wang, S., Peng, Y. (2010): Natural zeolites as effective adsorbents in water and wastewater treatment. - Chem. Eng. J. 156: 11-24.

[45] Wang, P., Tang, L., Wei, X., Zeng, G., Zhou, Y., Deng, Y., Wang, J., Xie, Z., Fang, W. (2017): Synthesis and application of iron and zinc doped biochar for removal of pnitrophenol in wastewater and assessment of the influence of co-existed $\mathrm{Pb}$ (II). - Appl. Surf. Sci. 392: 391-401.

[46] Wu, C., Huang, L., Xue, S. G., Huang, Y. Y., Hartley, W., Cui, M. Q., Wong, M. H. (2017): Arsenic sorption by red mud-modified biochar produced from rice straw. - Environ. Sci. Pollut. Res. 24: 18168-18178.

[47] Xu, X., Cao, X., Zhao, L., Wang, H., Yu, H., Gao, B. (2013): Removal of Cu, Zn, Cd from aqueous solutions by the dairy manure-derived biochar. - Environ. Sci. Pollut. Res. 20: 358-368.

[48] Xu, X., Cao, X., Zhao, L., Zhou, H., Luo, Q. (2014): Interaction of organic and inorganic fractions of biochar with $\mathrm{Pb}$ (II) ion: Further elucidation of mechanisms for $\mathrm{Pb}$ (II) removal by biochar. - RSC Adv. 4: 44930-44937.

[49] Xu, W., Jian, H., Liu, Y., Zeng, G., Li, X., Gu, Y., Tan, X. (2015): Removal of Chromium (VI) from aqueous solution using mycelial pellets of penicillium simplicissimum impregnated with powdered biochar. - Biorem. J. 19: 259-268.

[50] Yang, Z. H., Wang, B., Chai, L. Y., Wang, Y. Y., Wang, H. Y., Su, C. Q. (2009): Removal of $\mathrm{Cr}(\mathrm{III})$ and $\mathrm{Cr}(\mathrm{VI})$ from aqueous solution by adsorption on sugarcane pulp residue. - J. Cent. South Univ. Technol. 16: 101-107.

[51] Zhang, Z. B., Cao, X. H., Liang, P., Liu, Y. H. (2013): Adsorption of uranium from aqueous solution using biochar produced by hydrothermal carbonization. - J. Radioanal. Nucl. Chem. 295: 1201-1208.

[52] Zhang, M., Liu, Y., Li, T., Xu, W., Zheng, B., Tan, X., Wang, H., Guo, Y., Guo, F., Wang, S. (2015): Chitosan modification of magnetic biochar produced from Eichhornia crassipes for enhanced sorption of $\mathrm{Cr}(\mathrm{VI})$ from aqueous solution. - RSC Adv. 5: 46955-46964.

[53] Zhao, Z., Wei, J., Li, F., Qu, X., Liang, S., Zhang, H., Yu, Q. (2017): Synthesis, characterization and hexavalent chromium adsorption characteristics of Aluminum- and sucrose-incorporated tobermorite. - Materials. 10: 597.

[54] Zhou, Y., Gao, B., Zimmerman, A. R., Fang, J., Sun, Y., Cao, X. (2013): Sorption of heavy metals on chitosan-modified biochars and its biological effects. - Chem. Eng. J. 231: 512518.

[55] Zhou, L., Huang, Y., Qiu, W., Sun, Z., Liu, Z., Song, Z. (2017): Adsorption properties of nano- $\mathrm{MnO}_{2}$-biochar composites for copper in aqueous solution. - Molecules 22: 173. 